\title{
Analisis Pola Persebaran Pencemaran Air Tanah di Sekitar Penambangan Sumur Minyak Tua Desa Wonocolo, Kedewan, Bojonegoro
}

\author{
(Analysis of Groundwater Pollution Distribution Patterns Around the Mining \\ of Old Oil Wells Wonocolo Village, Kedewan, Bojonegoro)
}

\author{
Subariswanti $^{1^{*}}$, Abdul Hakim ${ }^{1}$, dan Dedy Suprayogi ${ }^{1}$ \\ ${ }^{1}$ Teknik Lingkungan, Sains dan Teknologi, Universitas Islam Negeri Sunan Ampel Surabaya. \\ J1. Ahmad Yani Nomor 117, Kota Surabaya, Jawa Timur, Indonesia 60237. \\ *Penulis korespondensi: subariswanti1999@gmail.com
}

\begin{abstract}
Wonocolo Village is a traditional old oil well mining tourism area in Kedewan District, Bojonegoro Regency. This existence affects water quality because it is one of many factors causing groundwater pollution. The purpose study is to determine the distribution pattern of pollution such as iron, manganese, and zinc due to oil mining. Moreover, the study predicts the pattern of distribution of pollution in groundwater over a certain period of time. The method used for this study is groundwater modeling (MATLAB). Thus, determination of sampling based on SNI 6989.58:2008 with 3 (three) sampling points. The determination of the distribution pattern uses the parameters such as Iron, Manganese, and Zinc. The simulation results of the 2-dimensional distribution model and in the range in the next 18 years and 50 years. The prediction result for iron content is still in good condition. Meanwhile for manganese content and zinc content will be polluted after 50 years with a detected distance of $\pm 1150 \mathrm{~m}$ and $\pm 1400 \mathrm{~m}$ respectively from the contaminant source point.
\end{abstract}

Keywords: Water Quality, Old Oil Well Mining, Groundwater Modeling Method.

\section{PENDAHULUAN}

Air tanah merupakan sumber daya alam yang memiliki peranan penting. Secara umum air tanah memiliki peranan penting sekitar $70 \%$ untuk kebutuhan sumber air bersih yang utama di Indonesia (Yogafany, et al, 2020). Kemajuan peradaban menyebabkan suatu ancaman serius bagi air tanah, terutama dari segi kualitas. Penentuan kualitas air tanah dapat dilakukan secara efisiensi untuk memberikan gambaran mengenai analisis kualitas air tersebut (Yuniarti dan Danang, 2019). Salah satu sumber ancaman kualitas air tanah yaitu berasal dari kegiatan penambangan sumur minyak tua.
Penambangan minyak bumi yang dilakukan secara tradisional memiliki dampak yang positif seperti meningkatnya produksi hingga pendapatan minyak bumi terhadap masyarakat dalam skala nasional. Sedangkan, dampak negatif seperti pencemaran lingkungan dan healhty terhadap penambang untuk melaksanakan teknologi yang

sederhana (Hedar, 2018). Menurut informasi yang diperoleh dari Resourcce Governance in Asia Pasifik terdapat sebanyak 505 sumur minyak produksi, keberadaan sumur tersebut kemungkinan berpontensi mempengaruhi kualitas air tanah.

Penelitian terdahulu menyatakan bahwa minyak bumi dapat mencemari 
tanah hingga mencapai stasiun sumber air tanah yang menyuplai dan menyediakan untuk kebutuhan domestik. Sehingga menyebabkan permasalahan bagi kawasan yang masih menggunakan air tanah untuk sumber utama kebutuhan clean water dan lain-lain (Harnani, 2019). Penjelasan tersebut peneliti ini untuk mengetahui pola persebaran pencemaran dengan menggunakan perangkat lunak (Software) MATLAB atau pemodelan air tanah secara 2 dimensi.

Penelitian ini memiliki beberapa tujuan, pertama yaitu untuk mengetahui pola persebaran pencemaran seperti besi, mangan, dan seng akibat penambangan sumur minyak tua pada air tanah, yang kedua untuk memprediksi pola penyebaran pencemaran dalam air tanah dalam waktu tertentu. Berdasarkan analisis kualitas air tanah dilakukan dengan metode pemodelan air tanah (MATLAB). Sehingga harus diketahui sumber polutan, maka perlu adanya pola persebaran pencemaran mengenai akibat penambangan sumur minyak tua di Desa Wonocolo, Kedewan, Bojonegoro.

\section{METODOLOGI}

\section{Survey Pendahuluan}

Survey pendahuluan dilakukan untuk mengetahui keadaan lingkungan penambangan sumur minyak tua di Desa Wonocolo. Pada kegiatan survey ini juga dilakukan pengambilan tanah dan pengukuran muka air tanah sehingga diperoleh hasil yang diketahui pada kondisi daerah tersebut.

\section{Kualitas Air Tanah dan Analisis Tanah}

Pengujian kualitas air tanah dan analisis tanah dilakukan dengan pengambilan sampling awal 3 stasiun. Pengambilan sampel dilakukan pada siang hari, pukul $09.00-13.00$ WIB. Analisis kualitas air yang dilakukan di laboratorium yaitu besi ( $\mathrm{Fe})$, mangan $(\mathrm{Mn})$ dan seng ( $\mathrm{Zn})$. Pengambilan sampel tanah diambil $1.3 \mathrm{~g} / \mathrm{cm} 3$, kemudian densitas tanah dan pengambilan sampel air tanah dilakukan dengan pengumpulan data dan diperoleh dari pengujian laboratorium, kemudian mengidentifikasi pemodelan air tanah (MATLAB). Berikut dapat dilihat pada Gambar 1. Diagram Alir Penelitian. 


\section{Ide Penelitian:}

Analisis Pola Persebaran Air Tanah disekitar Penambangan Sumur Minyak Tua Desa Wonocolo, Kedewan, Bojonegoro

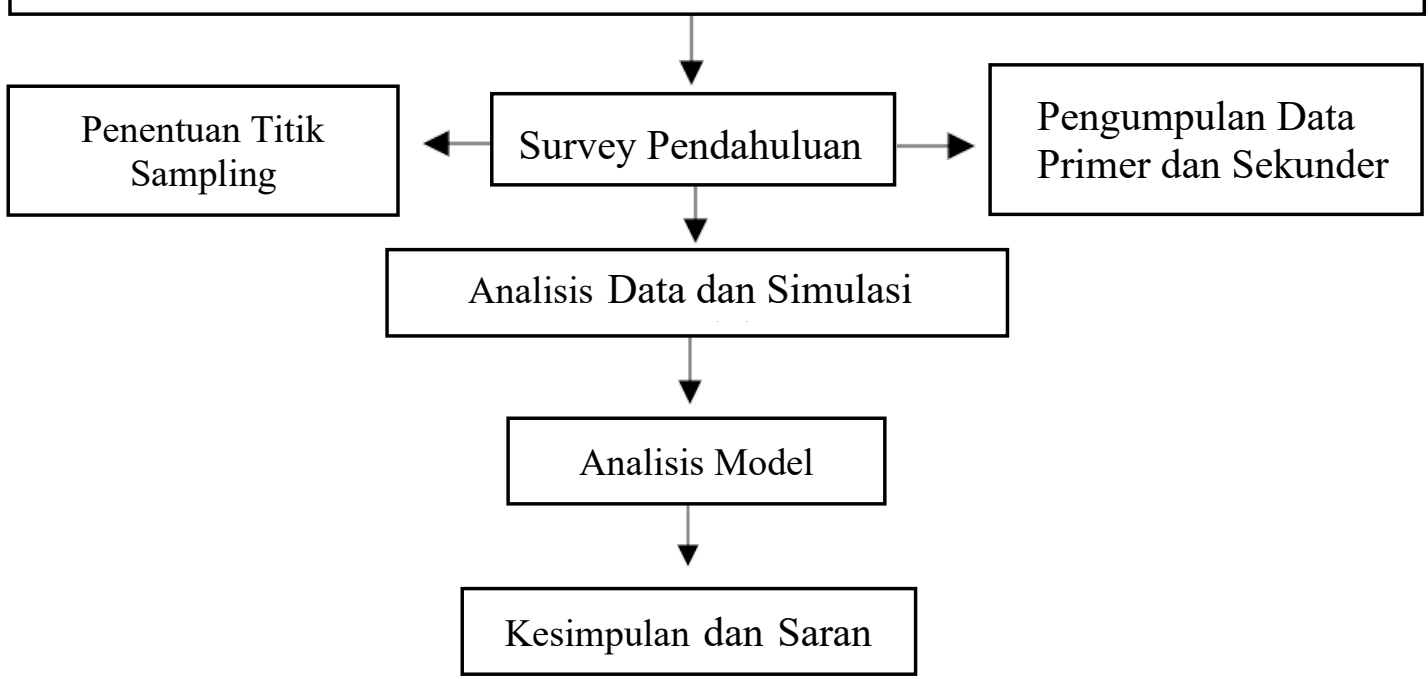

Gambar 1 Diagram Alir Penelitian

\section{Model Analitik}

Metode Analitik terhadap pemodelan air tanah dan pengolahan data menggunakan pengembangan model rumus Domenico Robbins untuk pemodelan dengan komponen concervative (Purba, 2014). Sehingga dapat dilihat rumus solusi Domenico sebagai berikut :

$$
\begin{aligned}
& C_{(x, y, z, t)}=\left(\frac{C_{0}}{8}\right) \exp \left\{\left(\frac{x}{2 \alpha_{x}}\right)\left[1-\left(1+\frac{4 \lambda \alpha_{x}}{v}\right)^{\frac{1}{2}}\right]\right\} \\
& \operatorname{erfc}\left[\frac{R x-v t\left(1+\frac{4 \lambda \alpha_{x}}{v}\right)^{\frac{1}{2}}}{2\left(R \alpha_{x} v t\right)^{\frac{1}{2}}}\right]\left\{\operatorname{erf}\left[\frac{\left(y+\frac{Y}{2}\right)}{2\left(\alpha_{y} x\right)^{\frac{1}{2}}}\right]-\operatorname{erf}\left[\frac{\left(y-\frac{Y}{2}\right)}{2\left(\alpha_{y} x\right)^{\frac{1}{2}}}\right]\right\} \\
& \left\{\operatorname{erf}\left[\frac{\left(z+\frac{z}{2}\right)}{2\left(\alpha_{z} x\right)^{\frac{1}{2}}}\right]-\operatorname{erf}\left[\frac{\left(z-\frac{z}{2}\right)}{2\left(\alpha_{z} x\right)^{\frac{1}{2}}}\right]\right\}
\end{aligned}
$$

\begin{tabular}{|c|c|c|c|}
\hline \multicolumn{2}{|c|}{ Keterangan : } & $v$ & $=$ speed water ground \\
\hline$C$ & $=$ contaminant consentration & $t$ & $=$ time \\
\hline$x$ & $=$ distance from the source of & $\lambda$ & $=$ decay rate \\
\hline$y$ & $\begin{array}{l}\text { the contaminant } \\
=\text { distance from the central }\end{array}$ & $\begin{array}{l}Y \\
Z\end{array}$ & $\begin{array}{l}=\text { length of source area } \\
=\text { thickness of groundwater }\end{array}$ \\
\hline & $\begin{array}{l}\text { location of the contaminant } \\
\text { source }\end{array}$ & $\begin{array}{l}\alpha_{\mathrm{x}} \\
\alpha_{\mathrm{y}}\end{array}$ & $\begin{array}{l}=\text { dispersitivitas } \mathrm{x} \\
=\text { dispersitivitas } \mathrm{y}\end{array}$ \\
\hline & $=$ vertical distance & $\alpha_{z}$ & $=$ dispersitivitas $\mathrm{z}$ \\
\hline
\end{tabular}


Perhitungan yang digunakan secara model rumus Domenico menggunakan solusi 2 dimensi dengan jarak $1 \mathrm{~km}, 1.5 \mathrm{~km}$ dan $2 \mathrm{~km}$ dari penambangan ke pemukiman. Mengenai hasil pemodelan akan dilakukan adanya prediksi. Prediksi ini untuk mengetahui bagaimana kondisi yang dilakukan terhadap kondisi lingkungan, prediksi persebaran pencemaran air tanah pada jangka waktu 18 tahun dan 50 tahun yang akan mendatang.

\section{HASIL DAN PEMBAHASAN}

Menurut data Badan Pusat Statistik Kecamatan Kedewan dalam angka 2019, jumlah penduduk Desa Wonocolo pada 2018 sebanyak 2.071 jiwa dan luas desa sekitar $11.37 \mathrm{~km}^{2}$. Pengambilan sampel dilakukan di daerah Desa Wonocolo, Kedewan, Bojonegoro. Metode pengambilan sampel yang digunakan adalah metode duplikat berdasarkan SNI 6989.58: 2008 mengenai Metode Pengambilan Sampel Air Tanah. Pengambilan sampel air tanah dilakukan sebanyak $2 x$ dengan 3 stasiun dan masing masing sampel sekitar 2 liter. Koordinat dari setiap titik dicatat kemudian dimasukan dalam peta stasiun. Berikut dapat dilihat pada Gambar 2.

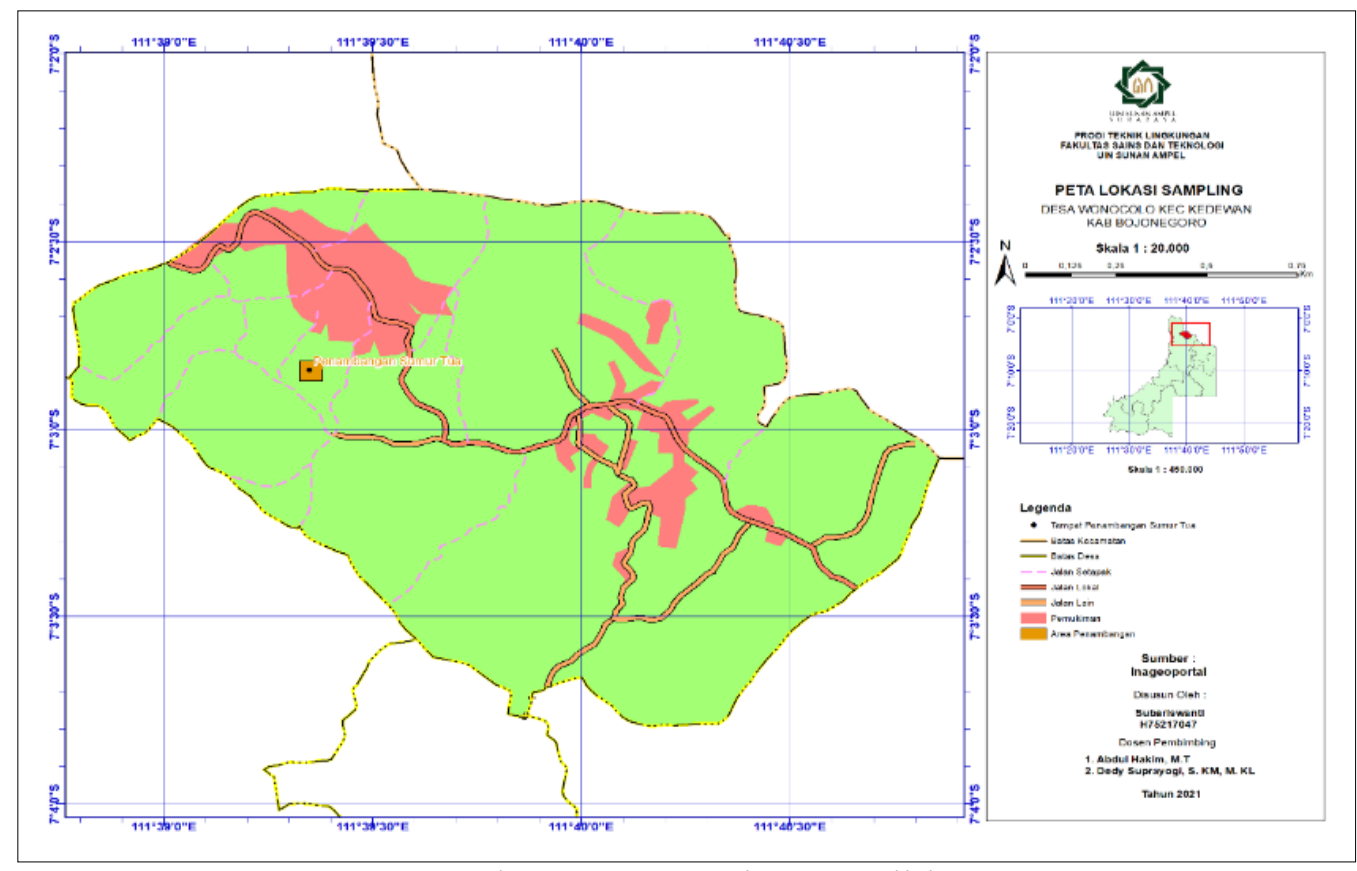

Gambar 2 Peta Stasiun Penelitian

\section{Analisis Kualitas Air Tanah Desa Wonocolo}

Air tanah yang berada di daerah studi penelitian digunakan sebagai air bersih oleh penduduk sekitar. Kualitas air tanah dapat di analisis untuk mengetahui dan dilakukan di Desa wonocolo dengan menggunakan parameter besi, mangan dan seng sehingga dapat dijelaskan sebagai berikut: 


\section{a. Besi (Fe)}

Tabel 1 Kadar Besi (Fe) pada Air Tanah

\begin{tabular}{|c|c|c|c|c|c|}
\hline $\begin{array}{c}\text { Desa } \\
\text { Wonocolo }\end{array}$ & $\begin{array}{c}\text { Hasil } \\
\text { Pengujian }\end{array}$ & Rata-Rata & $\begin{array}{c}\text { Standar } \\
\text { Baku } \\
\text { Mutu }\end{array}$ & Satuan & Keterangan \\
\hline Stasiun 0 & 0.25 & 0.25 & \multirow{7}{*}{1} & \multirow{7}{*}{$\mathrm{mg} / \mathrm{l}$} & \multirow{7}{*}{$\begin{array}{c}\text { Sesuai Baku } \\
\text { Mutu }\end{array}$} \\
\hline Stasiun 1 & 0.1 & \multirow{2}{*}{0.08} & & & \\
\hline & 0.06 & & & & \\
\hline \multirow[t]{2}{*}{ Stasiun 2} & 0.02 & \multirow{2}{*}{0.01} & & & \\
\hline & 0.02 & & & & \\
\hline \multirow[t]{2}{*}{ Stasiun 3} & 0.05 & \multirow{2}{*}{0.04} & & & \\
\hline & 0.03 & & & & \\
\hline
\end{tabular}

\section{b. Mangan (Mn)}

Tabel 2 Kadar Mangan (Mn) pada Air Tanah

\begin{tabular}{|c|c|c|c|c|c|}
\hline $\begin{array}{c}\text { Desa } \\
\text { Wonocolo }\end{array}$ & $\begin{array}{c}\text { Hasil } \\
\text { Pengujian }\end{array}$ & Rata-Rata & $\begin{array}{c}\text { Standar Baku } \\
\text { Mutu }\end{array}$ & Satuan & Keterangan \\
\hline Stasiun 0 & 0.072 & 0.072 & \multirow{7}{*}{0.5} & \multirow{7}{*}{$\mathrm{mg} / \mathrm{l}$} & \multirow{7}{*}{$\begin{array}{l}\text { Sesuai Baku } \\
\text { Mutu }\end{array}$} \\
\hline Stasiun 1 & 0.007 & \multirow{2}{*}{0.007} & & & \\
\hline & 0.006 & & & & \\
\hline \multirow[t]{2}{*}{ Stasiun 2} & 0.003 & \multirow{2}{*}{0.003} & & & \\
\hline & 0.003 & & & & \\
\hline \multirow[t]{2}{*}{ Stasiun 3} & 0.006 & \multirow{2}{*}{0.007} & & & \\
\hline & 0.008 & & & & \\
\hline
\end{tabular}

\section{c. Seng (Zn)}

Tabel 3 Kadar Seng (Zn) pada Air Tanah

\begin{tabular}{|c|c|c|c|c|c|}
\hline $\begin{array}{c}\text { Desa } \\
\text { Wonocolo }\end{array}$ & $\begin{array}{c}\text { Hasil } \\
\text { Pengujian }\end{array}$ & Rata-Rata & $\begin{array}{c}\text { Standar Baku } \\
\text { Mutu }\end{array}$ & Satuan & Keterangan \\
\hline Stasiun 0 & 0.5 & 0.5 & \multirow{7}{*}{15} & \multirow{7}{*}{$\mathrm{mg} / \mathrm{l}$} & \multirow{7}{*}{$\begin{array}{c}\text { Sesuai Baku } \\
\text { Mutu }\end{array}$} \\
\hline \multirow[t]{2}{*}{ Stasiun 1} & 0.1 & \multirow{2}{*}{0.2} & & & \\
\hline & 0.2 & & & & \\
\hline \multirow[t]{2}{*}{ Stasiun 2} & 0.1 & \multirow{2}{*}{0.2} & & & \\
\hline & 0.2 & & & & \\
\hline \multirow[t]{2}{*}{ Stasiun 3} & 0.1 & \multirow{2}{*}{0.1} & & & \\
\hline & 0.1 & & & & \\
\hline
\end{tabular}

Berdasarkan Tabel 1, 2 dan 3 menunjukkan bahwa nilai rata-rata analisis kualitas air tanah pada hasil pengujian kadar kadar Besi (Fe), Mangan (Mn) dan Seng (Zn) di Desa
Wonocolo masih sesuai dengan baku mutu yang ditetapkan dari Permenkes Republik Indonesia Nomor 32 Tahun 2017. Hal tersebut air tanah masih layak digunakan untuk air bersih, dan 
kemudian setelah itu maka akan di gunakan untuk pemodelan air tanah agar dapat mengetahui pola persebaran kontaminan yang akan datang dengan aplikasi model analitik.

\section{Aplikasi Model Analitik}

Solusi model analitik terhadap persebaran kontaminan menggunakan rumus Domenico-Robins secara 2 dimensi dengan aplikasi MATLAB

(Notodarmojo, 2005). Parameter yang digunakan untuk pemodelan air tanah seperti kadar kadar besi (Fe), Mangan (Mn) dan Seng (Zn). Kemudian melakukan simulasi model dengan asumsi dasar untuk pengembangan model solusi analitik. Berikut dapat dilihat pada Tabel 4.

Tabel 4 Asumsi Dasar untuk Pengembangan Model Solusi Analitik

\begin{tabular}{l|c|c}
\hline \multicolumn{1}{c|}{ Parameter } & Nilai & Unit \\
\hline Time & 18 & Tahun \\
\hline Eid Source & 114 & $\mathrm{~m}$ \\
\hline Source Depth & 300 & $\mathrm{~m}$ \\
\hline Porositas & 0.49 & - \\
\hline Konduktivitas Hidrolis & 0.365 & $\mathrm{~m} / \mathrm{tahun}$ \\
\hline Koefisien distribusi & & \\
\hline a. Besi (Fe) & 0.7 & $\mathrm{~L} / \mathrm{kg}$ \\
\hline b. Mangan (Mn) & 0.14 & $\mathrm{~L} / \mathrm{kg}$ \\
\hline c. Seng (Zn) & 0.30 & $\mathrm{~L} / \mathrm{kg}$ \\
\hline Dispersivity Longitudinal & $0.1 * \mathrm{x}$ & $\mathrm{m}$ \\
\hline Dispersivity Transversal & $0.33^{*} \mathrm{ax}$ & $\mathrm{m}$ \\
\hline Dispersivity Universal & $0.056^{*} \mathrm{ax}$ & $\mathrm{m}$ \\
\hline Densitas Tanah & 0.11 & $\mathrm{~g} \mathrm{~cm}-{ }^{-3}$ \\
\hline Konsentrasi Kontaminan & & \\
\hline a. Besi (Fe) & 0.25 & $\mathrm{mg} / \mathrm{l}^{-1}$ \\
\hline b. Mangan (Mn) & 0.072 & $\mathrm{mg} / \mathrm{l}^{-1}$ \\
\hline c. Seng (Zn) & 0.5 & $\mathrm{mg} / \mathrm{l}^{-1}$ \\
\hline
\end{tabular}

Data asumsi dasar diperoleh dari studi literatur dan data lapangan pada penelitian. Kedalaman penambangan sumur minyak tua sekitar 300 meter. Sehingga apabila adanya limbah buangan tersebut maka akan mengalir ke aliran sungai dan akan berpotensi mencemari air tanah atau sumur gali yang digunakan oleh penduduk Desa Wonocolo. Kemudian mengetahui porositas tanah sebesar 0.49 dengan jenis tanah yang berkapur dan kelas sedang (Yuliany, 2016).

Berdasarkan pada analisis karakteristik tanah untuk nilai terhadap konduktivitas hidrolis menggunakan 0.365 meter/hari (Pirdriansy, 2013). Selanjutnya mengetahui koefisien distribusi yang merupakan concentration ratio. Semakin banyak logam terlarut maka semakin kecil nilainya. Menurut Sukarjo (2019) untuk mengetahui koefisien distribusi parameter besi $(\mathrm{Fe})$ yaitu memiliki nilai $0.7 \mathrm{~m} / \mathrm{kg}$, sedangkan parameter mangan (Mn) $0.14 \mathrm{~m} / \mathrm{kg}$ dan seng ( $\mathrm{Zn}$ ) 0.30 $\mathrm{m} / \mathrm{kg}$. 


\section{Hasil Simulasi Model}

Hasil simulasi model persebaran kadar Besi (Fe), Mangan (Mn), Seng (Zn) terhadap air tanah dilakukan secara dua dimensi. Asumsi yang digunakan sesuai dengan konsentrasi pencemaran atau disebut konstan. Kemudian memprediksi dengan daya jangkau rentang 18 dan 50 tahun. Prediksi tersebut merupakan inti yang utama dari suatu pemodelan dan akan digunakan untuk melihat bagaimana keadaan terhadap kondisi lingkungan pada tahun yang akan datang di Desa Wonocolo.

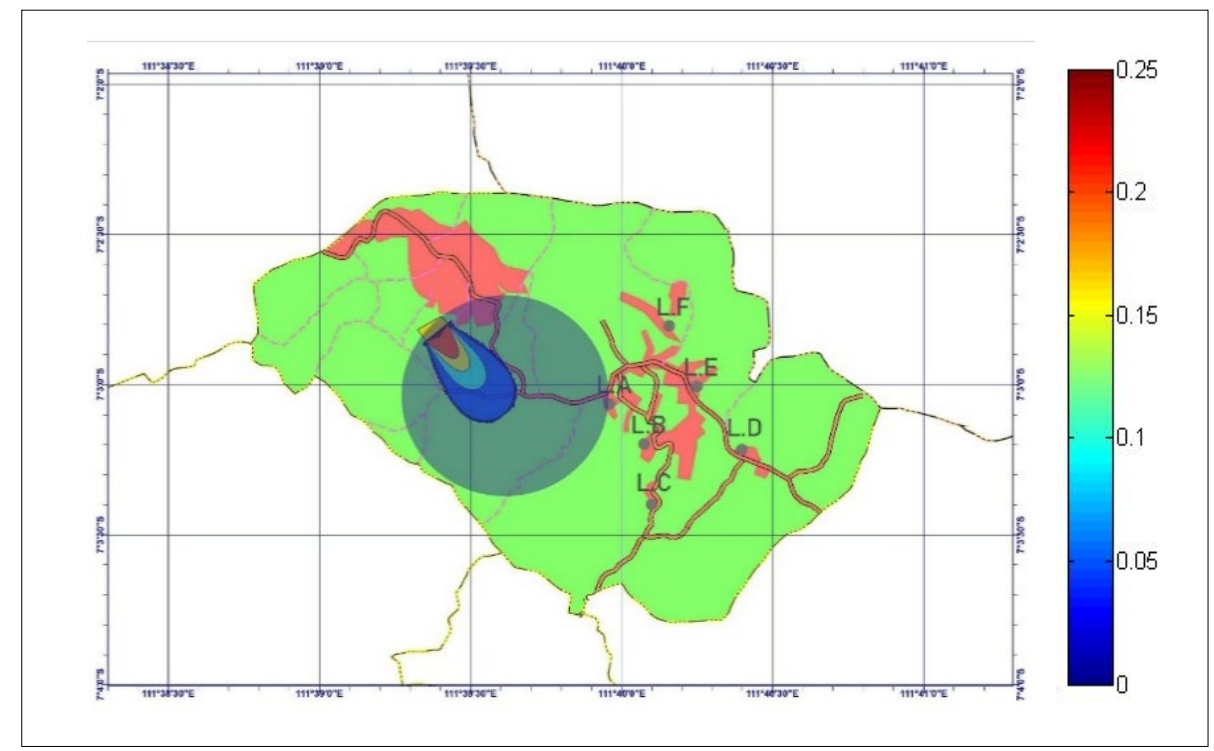

Gambar 3 Hasil Simulasi Fe

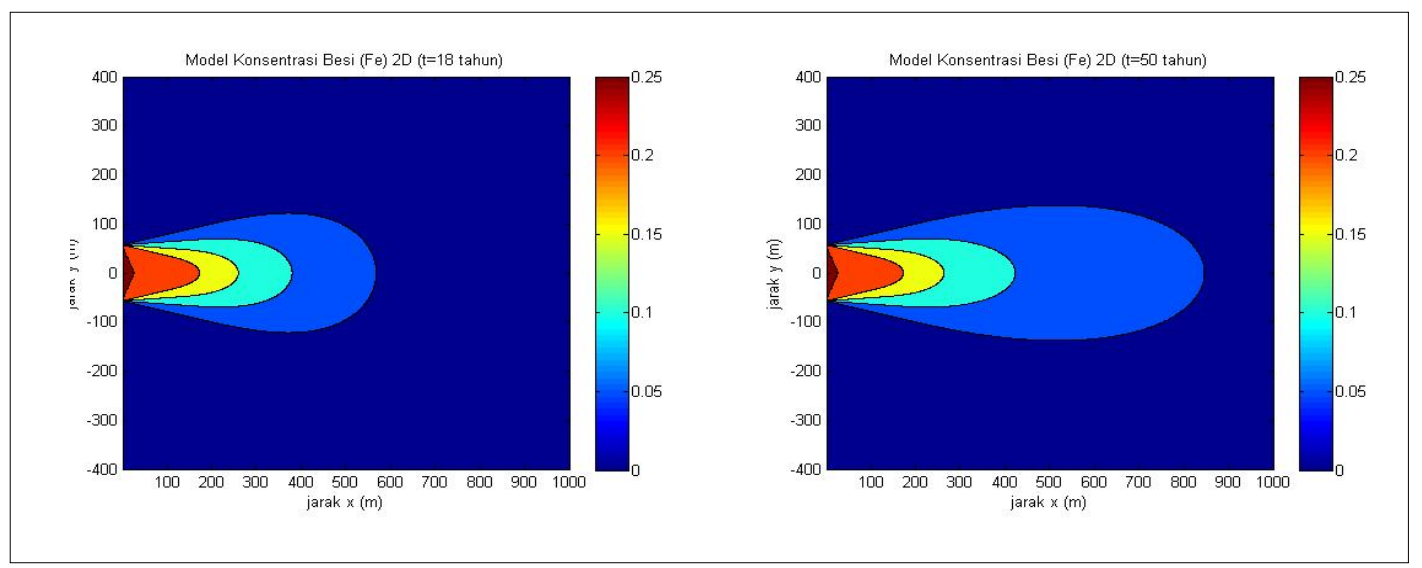

Gambar 4 Persebaran Kadar Besi (Fe)

Hasil pengujian dari laboratorium pada parameter kadar besi yaitu $0.25 \mathrm{~m} / \mathrm{kg}$ dengan koefisien distribusi $0.7 \mathrm{~L} / \mathrm{kg}$. Kemudian dilakukan hasil simulasi model, dengan persebaran kadar besi yang masih terdeteksi pada jarak \pm 600 meter dan 50 tahun terdeteksi jarak \pm 850 meter dari tempat penambangan sumur minyak tua atau sumber pencemar. Sehingga dapat diketahui apabila semakin lama usia penambangan, maka persebaran kadar besi akan semakin jauh pada tahun yan akan datang. 


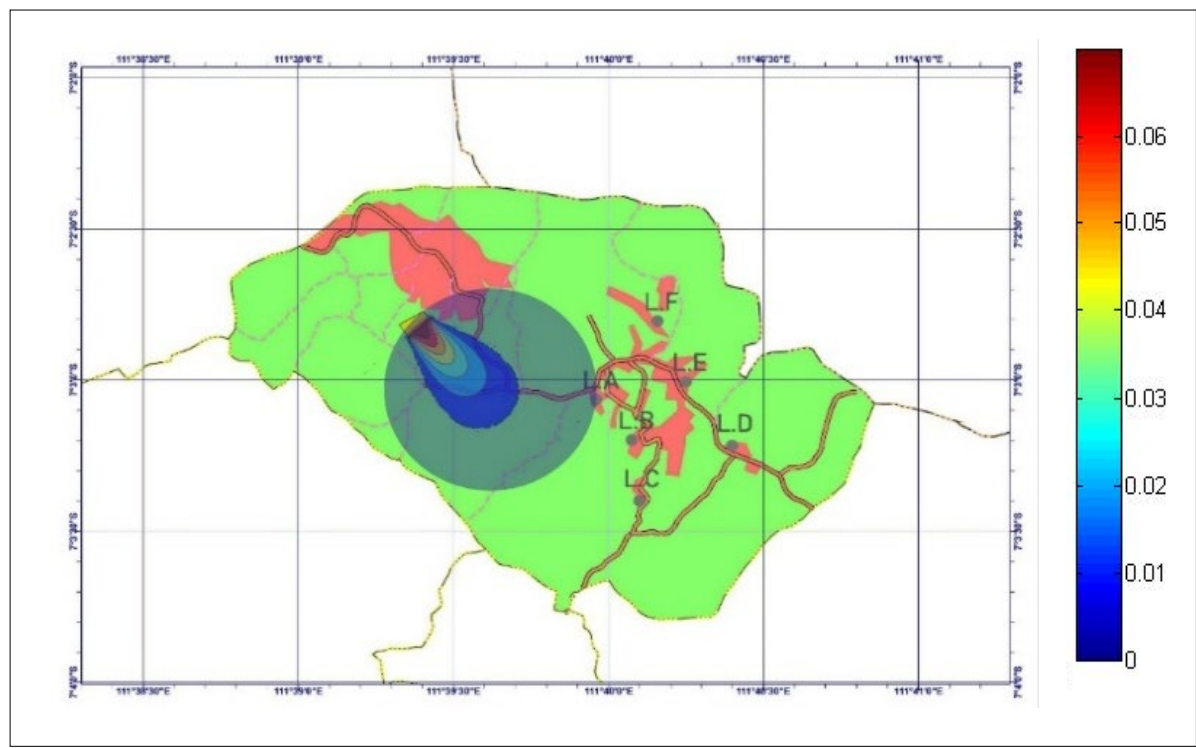

Gambar 5 Hasil Simulasi Mn

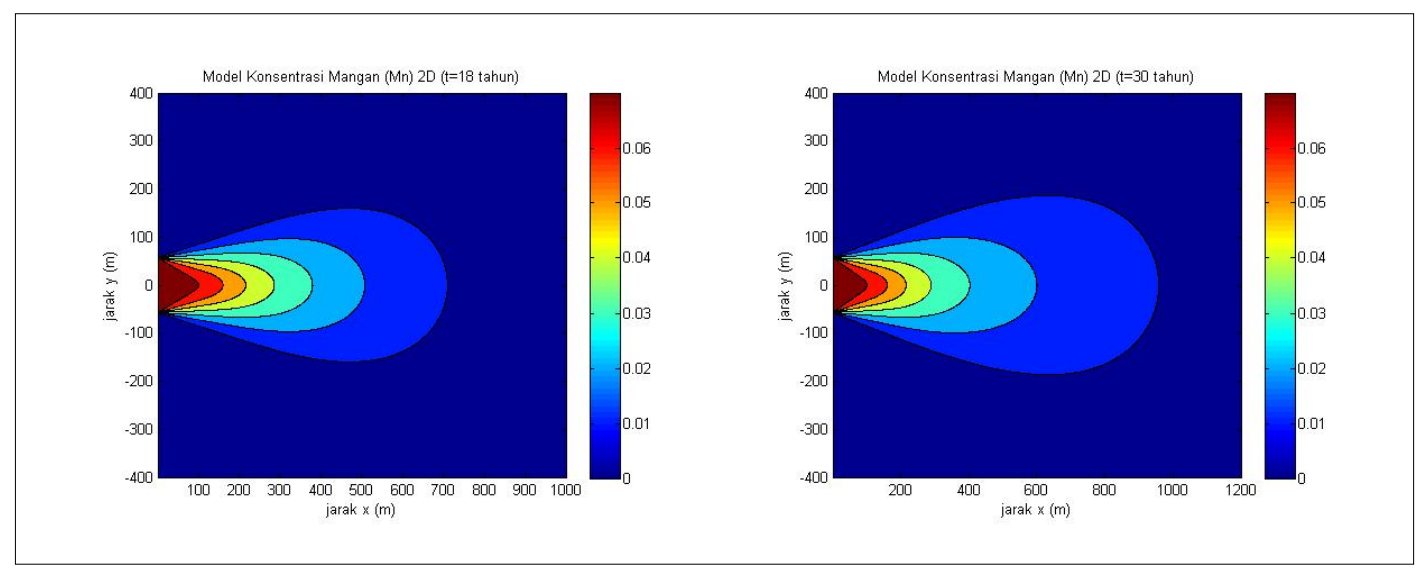

Gambar 6 Persebaran Kadar Mangan (Mn)

Hasil pengujian dari laboratorium pada parameter mangan yaitu $0.072 \mathrm{~m} / \mathrm{kg}$ dengan koefisien distribusi $0.14 \mathrm{~L} / \mathrm{kg}$. Kemudian dilakukan hasil simulasi model, persebaran kadar kadar mangan masih terdeteksi pada jarak \pm 700 meter dan 50 tahun terdeteksi jarak \pm 1150 meter dari lokasi penambangan sumur minyak tua atau sumber pencemar. Sehingga dapat diketahui apabila semakin lama usia penambangan, maka persebaran kadar mangan akan semakin jauh dan akan membahayakan terhadap esehatan penduduk sekitar. 


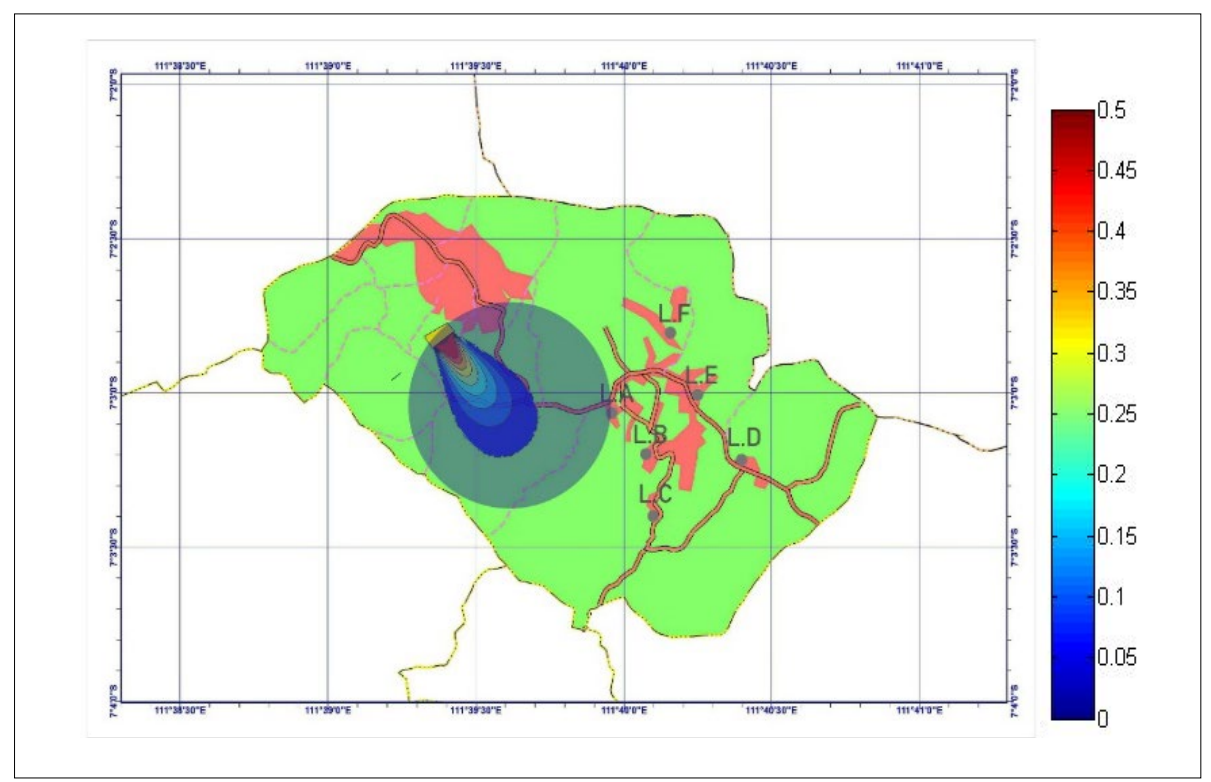

Gambar 7 Hasil Simulasi Zn

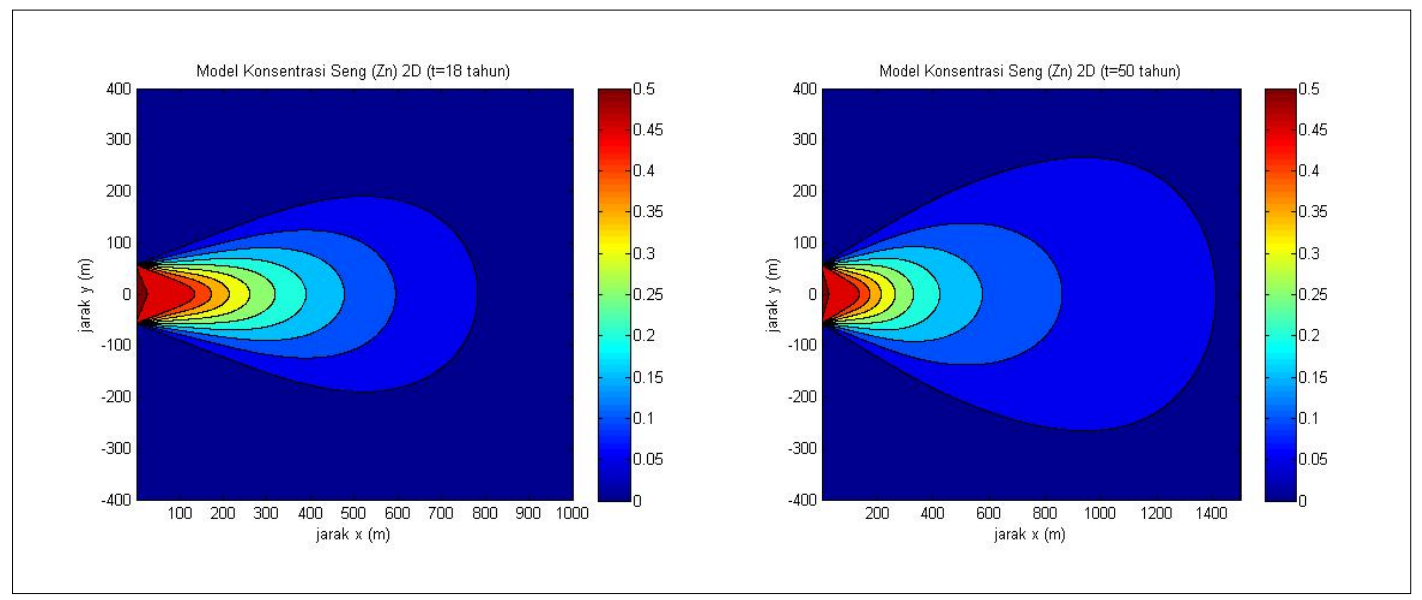

Gambar 8 Persebaran Kadar Seng (Zn)

Hasil pengujian dari laboratorium pada parameter Seng yaitu $0.5 \mathrm{~m} / \mathrm{kg}$ dengan koefisien distribusi $0.30 \mathrm{~L} / \mathrm{kg}$. Kemudian dilakukan hasil simulasi model, persebaran kadar kadar seng pada 18 tahun masih terdeteksi jarak \pm 800 meter dan 50 tahun terdeteksi jarak \pm 1400 meter dari lokasi penambangan sumur minyak tua atau sumber pencemar. Sehingga penduduk yang tinggal disekitar Desa Wonocolo tersebut dapat membahayakan, dengan jarak $\pm 1000-1400 \mathrm{~m}$ dari penambangan sumur minyak tua secara tradisional. Apabila diketahui bahwa semakin lama usia penambangan terhadap persebaran kadar seng maka, akan semakin jauh dan akan membahayakan kesehatan penduduk.

\section{KESIMPULAN}

Berdasarkan analisis yang dilakukan, maka dapat ditarik kesimpulan sebagai berikut:

1. Hasil kualitas air tanah menunjukkan bahwa semua parameter seperti Fe, Mn, dan Zn, masih memenuhi standar baku mutu pada Permenkes Republik Indonesia Nomor 32 Tahun 2017. 
2. Hasil simulasi pola model persebaran secara 2 dimensi dengan daya jangkau dalam rentang 18 tahun dan 50 tahun yang akan mendatang. Hasil prediksi menunjukkan bahwa dalam kadar besi (Fe) masih kondisi baik, sedangkan pada kadar mangan $(\mathrm{Mn})$ akan tercemar setelah 50 tahun dengan terdeteksi jarak $\pm 1150 \mathrm{~m}$ dan pada kadar seng ( $\mathrm{Zn}$ ) akan tercemar setelah 50 tahun terdeteksi jarak $\pm 1400 \mathrm{~m}$ dari stasiun sumber pencemaran.

\section{DAFTAR PUSTAKA}

Badan Standarisasi Nasional. (2008). SNI 6989.58:2008 tentang Metode Pengambilan Sampel Air Tanah.

Hedar (2018). The Influence of Traditional Petroleum Traditional Mining Activities on Old Wells on River-Water Quality in Wonocolo Village, Kedewan, Bojonegoro. Semarang: Master Thesis. Diponegoro University.

Notodarmojo. (2005). Pencemaran Tanah dan Air Tanah. Bandung: Penerbit ITB.

Permatasari. (2016). Analisis Penurunan Kadar Besi dan Kadar Mangan dalam Air Sumur Gali dengan Metode Aerasi Filter. Skripsi.

Pidriansy, (2013). Kajian Pencemaran ir Tanah dan Analisis Risiko Kesehatan Manusia Akibat Lindi dari Landfill. Tesis. Teknik Lingkungan. ITB Bandung.

Purba, Deardo. (2014). Analisis Pola Penyebaran Pencemaran pada Air Tanah dangkal Akibat Lindi Di Tempat Pengelolaan Akhir Jatibarang, Tesis. Semarang.
Sukarjo, (2019). Penilaian Resiko Kontaminasi Logam Berat daerah Brantas, Kabupaten Jombang. Jurnal Tanah dan Sumberdaya Lahan. Vol. 6, No. 1.

Yogafany, E., Titi Tiara A., san Vindi Vadia U. (2020). Zonation of ground water vulnerability using COP and APLIS methods in Gremeng Watershed, Umbulrejo, Ponjong, Gunungkidul. Journal of Watershed Management Research, Vol. 4, No. 2.

Yuliany (2016). Provision of Teak Leaf Litter to Increase Nutrient Levels and Soil Physical Properties in Limestone Soil Wonocolo Village, Bojonegoro.

Yuniarti dan Danang B. (2019). Analisis Kualitas Air dengan Penentuan Status Mutu Air Sungai Jaing Kabupaten Tabalong. Jurnal Teknik Lingkungan, Vol 5, No 2. 